\title{
THE GENERAL SYNOD OF THE CHURCH OF ENGLAND
}

\author{
BRIAN HANSON \\ Joint Registrar of the Province of Canterbury
}

\begin{abstract}
THIS REPORT COVERS TWO GROUPS OF SESSIONS IN JULY AND NOVEMBER 1999.
\end{abstract}

The Synod met in residential session at York University in July and had a heavy programme of liturgical business in preparation for the authorisation of the new Service Book entitled Common Worship to replace the Alternative Service Book at the end of December 2000. By contrast the legislative items were fairly light. The Legislative Committee brought a report to Synod on the Churchwardens Measure and recommended its re-introduction in order that clause 9 could be withdrawn (which had caused difficulties for the Ecclesiastical Committee of Parliament) and a new clause on suspension substituted. The Synod agreed a new clause giving four grounds for suspension, namely (1) where the person has requested or consented to the suspension; (2) where the person is unable to carry out his duties by reason of absence, illness or incapacity; (3) where the person has been charged with an offence which is punishable with imprisonment or, if not so punishable, would on conviction disqualify that person from being chosen as churchwarden: and (4) where the person has been convicted of any offence which is punishable by imprisonment. The Synod also agreed a new clause requiring the House of Bishops to draw up principles of guidance for bishops exercising the power of suspension and a clause giving a right of appeal for a person who has received a notice of suspension to the Dean of the Arches and Auditor. On the expedited procedure the General Synod gave final approval to the Measure as amended (bishops, 22:0; clergy, 161:1: laity, 177:20). The Measure has now been returned to the Ecclesiastical Committee.

The Church of England (Miscellaneous Provisions) Measure (see 5 Ecc LJ 210) received both its revision and final approval stages at the July sessions and has been submitted to the Ecclesiastical Committee. Draft Amending Canon No. 22 (see 5 Ecc LJ 209) and draft Amending Canon No. 23 (see 5 Ecc LJ 210) were considered at final drafting stage and were referred to the House of Bishops, being items of Article 7 business.

Amendments to the Church Representation Rules were given final approval (see 5 Ecc LJ 209) and the Care of Places of Worship Rules were given deemed approval. The rules were required following the passing of the Care of Places of Worship Measure 1999 (see 5 Ecc LJ 209 and 5 Ecc LJ 65).

General Approval was also given to the draft Ecclesiastical Jurisdiction (Discipline) Measure which had been drafted following the debate on the report Under Authority in the Synod in November 1996. The draft Measure makes no change in discipline matters relating to doctrine. ritual and ceremonial, which is the subject of a separate review under the Chairmanship of the Bishop of Birmingham. The Measure differs from the report in that there is not to be a national tribunal but a bishop's disciplinary tribunal consisting of three persons drawn from provincial panels. The Archbishops' Caution List is to be given statutory force with defined rights given to clerics and to bishops. The Measure is now with a Revision Committee and. in addition to proposals for amendment from Synod members, a substantial paper has been submitted by the Ecclesiastical Law Society Working Party on Discipline. The Committee hope to report back to Synod at the February Group of Sessions.

At the November 1999 Sessions final approval was given to Amending Canons Nos 22 and 23 referred to above. The petitions for the Royal Licences were adopted and promulgation should take place at the February sessions. The draft Synodical 
Government (Amendment) Measure was given deemed first consideration (a new term in Standing Orders which replaces the general approval stage). The Measure gives additional functions to the diocesan synod with regard to the annual budget and annual accounts for the diocese and amends the Pastoral Measure 1983 by requiring the diocesan pastoral committee to review conventional districts at least once in five years. The other provisions amend the Church Representation Rules to enact recommendations of the Bridge Report which attracted broad support from dioceses as being uncontroversial. The Measure is now remitted to a Revision Committee.

A further recommendation of the Bridge Report that the Bishop of Dover should be an ex officio member of the Upper House of Canterbury Convocation and of the General Synod was embodied in draft Amending Canon No. 25, which had its first consideration and revision stages at the November sessions. The Canon will come back to the Synod for final approval in February with a view to promulgation in July in time for the General Synod elections. Deemed approved was given to other small election changes contained in the Convocations (Elections to Upper House) (Amendment) Rules and the Religious Communities (Lay Representatives) (Amendment) Rules. The Payments to the Churches Conservation Trust Order was also approved; this lays down the basis for the Church's financial contribution to the Churches Conservation Trust (formerly the Redundant Churches Fund) during the funding period to 31 March 2003. A maximum sum of $£ 12.6 \mathrm{~m}$ has been agreed with the government of which the Church will provide up to $£ 3.7 \mathrm{~m}(30 \%)$.

\title{
THE GOVERNING BODY OF THE CHURCH IN WALES
}

\author{
CHARLES ANDERSON \\ Solicitor to the Province of Wales
}

\section{THIS REPORT COVERS THE MEETINGS HELD AT LAMPETER ON 14/15 APRIL AND 22/23 SEPTEMBER 1999}

The meeting in April marked the imminent retirement of the Most Reverend Alwyn Rice-Jones, Bishop of St Asaph since 1982, Archbishop of Wales since 1991 and a member of the Governing Body for some forty years. A presentation was made to the Archbishop who retired at the end of June by the Bishop of Monmouth, the Right Reverend Dr Rowan Williams, speaking on behalf of the clergy, and $\mathrm{Mr}$ Richard Parkinson, Chairman of the Representative Body. on behalf of the laity.

In replying and expressing his appreciation of the sentiments expressed by both speakers and thanking the Governing Body for the gift of a cheque given to him to mark his retirement, the Archbishop recalled his long membership of the Governing Body and the wide range of experience which he had drawn from it. Later, in his final presidential address he recalled too the period of almost eighty years now passed since disestablishment, the special needs which arose from that time to establish the Province as an independent entity and to take account of sweeping social change in the years which have passed. These changes still continue, amongst the most recent being the changes enabling women to be ordained to the priesthood, the need to face and deal with the difficulties arising from the remarriage of people who have been divorced but whose previous partner is still alive, and the special arrangements which the Province has worked out for clergy who find themselves in such a position personally.

The Governing Body gave a First Reading to a Bill to establish a new Disciplinary Tribunal to make provision for the hearing of complaints against clergy and other members of the Church in Wales. This was a purely formal reading of the title of the 